\title{
Numerical simulations examining the possible role of anthropogenic and volcanic emissions during the 1997 Indonesian fires
}

\author{
Melissa Anne Pfeffer • Bärbel Langmann • \\ Angelika Heil • Hans-F. Graf
}

Received: 28 July 2010 / Accepted: 27 October 2010 / Published online: 2 December 2010

(C) The Author(s) 2010. This article is published with open access at Springerlink.com

\begin{abstract}
The regional atmospheric chemistry and climate model REMOTE has been used to conduct numerical simulations of the atmosphere during the catastrophic Indonesian fires of 1997. These simulations represent one possible scenario of the event, utilizing the RETRO wildland fire emission database. Emissions from the fires dominate the atmospheric concentrations of $\mathrm{O}_{3}, \mathrm{CO}, \mathrm{NO}_{2}$, and $\mathrm{SO}_{2}$ creating many possible exceedances of the Indonesian air quality standards. The scenario described here suggests that urban anthropogenic emissions contributed to the poor air quality due primarily to the fires. The urban air pollution may have increased the total number of people exposed to exceedances of the $\mathrm{O}_{3} 1$-h standard by $17 \%$. Secondary $\mathrm{O}_{3}$ from anthropogenic emissions enhanced the conversion of $\mathrm{SO}_{2}$ released by the fires to $\mathrm{SO}_{4}^{2-}$, demonstrating that the urban pollution actively altered the atmospheric behavior and lifetime of the fire emis-
\end{abstract}

M. A. Pfeffer

Max Planck Institute for Meteorology, Hamburg, Germany

B. Langmann

Institute of Geophysics, University of Hamburg,

Hamburg, Germany

\author{
A. Heil \\ Institute of Chemistry and Dynamics of the Geosphere, \\ Research Center Jülich, Jülich, Germany \\ H.-F. Graf \\ University of Cambridge, Cambridge, UK \\ Present Address: \\ M. A. Pfeffer $(\varangle)$ \\ Department of Geosciences, University of Oslo, \\ Oslo, Norway \\ e-mail:m.a.pfeffer@geo.uio.no
}

sions. Under the conditions present during the fires, volcanic $\mathrm{SO}_{2}$ emissions had a negligible influence on surface pollution.

Keywords Indonesia $\cdot$ Air pollution $\cdot$ Wildfires

\section{Introduction}

Air pollution is a significant environmental problem in Indonesia, having an impact on public health and disrupting the Indonesian economy (Aiken 2004). Elevated concentrations of lead, particulate matter (PM), carbon monoxide ( $\mathrm{CO}$ ), hydrocarbons, sulfur dioxide $\left(\mathrm{SO}_{2}\right)$, and nitrogen dioxide $\left(\mathrm{NO}_{2}\right)$ are found in all large cities in the country. Motor vehicles, fires, and the industrial sector are the greatest contributors to the air pollution problem (Energy Information Administration 2004). Additional sources of air pollution in Indonesia are volcanoes, as this is the region of the world with the largest number of historically active vents (Simkin and Siebert 1994). Large-scale fires set by people for land conversion contribute greatly during the dry season, releasing gases and particles referred to as haze into the atmosphere (Heil and Goldammer 2001). These fires are typically extinguished at the onset of the north monsoon rains in October-November. In 1997, however, strong El Niño conditions delayed the onset of the rains and promoted a drought (Khandekar et al. 2000), allowing the fires to burn uncontrolled for a longer time than usual. Between August and November 1997, land-clearing fires in Kalimantan and Sumatra grew out of control into wildfires producing an environmental disaster. The El Niño conditions also reduced convective activity in the region, preventing 
the emissions from the fires from mixing upwards in the atmosphere (Heil and Goldammer 2001). This had the effect of generating high surface concentrations of the pollutants that were transported over a large part of Southeast Asia. While Indonesia experienced the brunt of the pollution effects from the fires (Frankenberg et al. 2004), a multitude of transboundary health and economic problems, significantly in Malaysia (Sastry 2002; Khandekar et al. 2000) and Singapore (Koe et al. 2001), were also felt. The 1997 fires and their effects have been studied using several different methods, including stationary, balloon, and airplane measurements, satellite observations, illness and mortality surveys, and numerical modeling of atmospheric processes.

The surface and tropospheric concentrations of the compounds emitted by the fires including $\mathrm{PM}, \mathrm{SO}_{2}$, $\mathrm{CH}_{4}, \mathrm{CO}, \mathrm{NO}_{x}$, and secondarily produced $\mathrm{O}_{3}$ were enhanced within the region for all observed pollutants (Davies and Unam 1999; Fujiwara et al. 1999, 2000; Matsueda et al. 1999; Tsutsumi et al. 1999; Yonemura et al. 2002a, b). Even measurements performed several hundred kilometers from the fires demonstrated significantly elevated concentrations for all of these compounds. Satellite observations of this event are important, as there are very few ground-level observations of the extent of the area burned and of the dispersion of the pollution from the fires. The extent of the fires and associated haze were observed using Advanced Very High Resolution Radiometer (AVHRR) data (Wooster et al. 1998; Fang and Huang 1998). Nakajima et al. (1999) used AVHRR data to study sulfate and carbonaceous aerosol optical thickness due to the fires, finding that the peak enhancement occurred in October and that the smoke from the fires was dominated by small submicron aerosol particles. The Total Ozone Mapping Spectrometer (TOMS) was used to observe tropospheric column $\mathrm{O}_{3}$ (TCO) and tropospheric water vapor (Chandra et al. 1998) and total atmospheric $\mathrm{O}_{3}$ (Kita et al 2000). TOMS indicated about 1020 Dobson Units (DU; 1 DU $=2.69 \times 10^{16}$ molecules $\mathrm{cm}^{-2}$ ) of increased tropospheric ozone over the Indonesian region (Chandra et al. 1998) while groundbased measurements indicated an increase of up to 35 DU (Fujiwara et al. 1999). By comparing AVHRR and TOMS data, Nakajima et al. (1999) suggest that sulfate aerosol particles may be observed further from the fires than carbonaceous aerosol particles because of the time required for $\mathrm{SO}_{2}$ released by the fires to convert to sulfate aerosol. Increased tropospheric column concentrations of $\mathrm{NO}_{2}, \mathrm{O}_{3}$, and $\mathrm{H}_{2} \mathrm{CO}$ were observed by the Global Ozone Monitoring Experiment (GOME) during the fires (Burrows et al. 1999).
Several studies of the environmental and radiative effects of the compounds emitted by the fires have been conducted using climate and aerosol models. A global chemical transport model with a mean climatological state rather than the actual meteorological conditions present during the fires was used by Hauglustaine et al. (1999) to study the increase in tropospheric $\mathrm{O}_{3}$ due to precursor species released by the fires. A global atmospheric chemistry and transport model was applied by Chandra et al. (2002) who demonstrated a strong enhancement of TCO over Indonesia and most of the western Pacific and a decrease in TCO in the eastern Pacific, concluding that both the emissions from the fires and El Niño specific meteorological conditions contributed to the $\mathrm{O}_{3}$ anomaly. Duncan et al. (2003) expanded on the work of Chandra et al. (2002) using the same model and gaseous emissions while adding the radiative effects of black carbon (BC) and organic carbon (OC) particles from the fires in their study. They found that the net effect of the fires was to reduce $\mathrm{OH}$ and the oxidizing capacity of the troposphere and to reduce radiative forcing at the Earth's surface, predominantly by OC and BC. Podgorny et al. (2003) applied an aerosol optical model producing results that agree with those of Duncan et al. (2003) that the aerosol particles released by the fires generated an enhancement in atmospheric solar heating and a corresponding decrease in solar flux reaching the surface over the equatorial region ranging from west of Indonesia to Papua New Guinea. A large uncertainty in these early studies is in the emission inventory applied for the fires, in particular the contribution of peat fires to total fire emissions. Langmann and Heil (2004) applied a regional atmospheric chemistry and climate model to compare different emission scenarios in order to better constrain how much particulate matter was released by the fires, and how much the burning of peat forest contributed to the total pollution.

The present work is a theoretical study that attempts to capture the complex interactions of the different emission sources during the Indonesian fires of 1997. We have conducted the first study of this event that applies a high-resolution regional model including full tropospheric chemistry. We have further included a new improved inventory of anthropogenic and wildfire emissions- the RETRO database (Schultz et al. 2008; Schultz 2007). In order to model the event as realistically as possible, we have also included volcanic $\mathrm{SO}_{2}$ emissions. Due to the scarcity of measurements during the event, however, this is a theoretical modeling study that cannot be properly validated. The goal of this study is to examine the atmospheric concentrations of trace gases during this event, and to consider how the 
anthropogenic and volcanic emissions in the region may have participated in the extreme pollution event due primarily to the fires.

\section{Experimental setup}

In this section, we will describe the experiments performed for this study. Firstly, the model will be introduced. Then, the inventories for the anthropogenic, fire, and volcanic emissions will be described. Finally, the three experiments performed for this work will be explained.

\section{Model}

The regional atmospheric chemistry model Regional Model with Tracer Extension (REMOTE; Langmann 2000) has been used for this study. REMOTE combines the physics of the regional climate model REMO 5.0 with tropospheric chemical equations for 63 chemical species; 158 gas phase reactions from the RADM II photochemical mechanism (Stockwell et al. 1990) are included. The chemical tracer transport mechanisms include horizontal and vertical advection (Smolarkiewitz 1983), convective up- and down-draft (Tiedtke 1989), and vertical diffusion (Mellor and Yamada 1974). Trace species can undergo chemical decay in the atmosphere or can be removed from the atmosphere by wet and dry deposition or transport out of the model boundaries. Forty-three longer-lived chemical species are transported between grid boxes, and 20 are calculated but too short-lived to be transported.

The model was applied with 20 vertical layers of increasing thickness between the Earth's surface and the $10 \mathrm{hPa}$ pressure level (approximately $23 \mathrm{~km}$ ). The model domain covers Indonesia and northern Australia $\left(91^{\circ} \mathrm{E}-141^{\circ} \mathrm{E} ; 19^{\circ} \mathrm{S}-8^{\circ} \mathrm{N}\right)$ with a horizontal resolution of $0.5^{\circ}$ (approximately $55 \mathrm{~km}$ ). Meteorological analysis data from the European Centre for Medium-Range Weather Forecasts (ECMWF) were used as boundary conditions every $6 \mathrm{~h}$. Results from a global chemical transport model (MOZART; Horowitz et al. 2003) simulation for the year 1990 (Granier et al. 2003) were used as chemical concentration boundary conditions every $6 \mathrm{~h}$ for 14 chemical species including $\mathrm{O}_{3}$ and $\mathrm{CO}$. Background concentrations for 25 other species (Chang et al. 1987) including $\mathrm{SO}_{2}$ and $\mathrm{SO}_{4}^{2-}$ were specified at the lateral model boundaries.

\section{Emission inventories}

The emissions have been divided into three categories: anthropogenic, fire, and volcanic. The fires were set by people and are hence an anthropogenic source. For the purposes of this paper, however, the fire emissions are treated as distinct from the other anthropogenic emissions. The anthropogenic and fire emissions include 18 and 19 species, respectively, including $\mathrm{SO}_{2}, \mathrm{CO}$, and $\mathrm{NO}_{2}$. Some of the anthropogenic species vary monthly while others are an annual mean in the inventory. The anthropogenic emissions with monthly values vary little, and so these emissions are shown for only October 1997. All fire species have large monthly variations, so the fire emissions are shown for September, October, and November 1997. The volcanic inventory was developed to be a realistic, conservative estimate averaged over the past century. These emissions are temporally constant and include only $\mathrm{SO}_{2}$ and $\mathrm{SO}_{4}^{2-}$. Sea spray generally contributes less than $20 \%$ to atmospheric $\mathrm{S}$ in Indonesia (Kloster 2006), and is not considered in this paper.

\section{Anthropogenic emissions}

The anthropogenic emission inventory (Table 1) was assembled using data available from the Global

Table 1 Indonesian anthropogenic emissions for October 1997

\begin{tabular}{|c|c|}
\hline Species & $\begin{array}{l}\text { Emissions } \\
\text { Gg } \\
\text { Oct. } 1997\end{array}$ \\
\hline Acetaldehyde $^{\mathrm{a}}$ & 22.3 \\
\hline Alkanes ${ }^{\mathrm{a}, \mathrm{f}}$ & 74.0 \\
\hline Aromatics $^{\mathrm{a}, \mathrm{g}}$ & 13.0 \\
\hline Black carbon $^{\text {b }}$ & 43.2 \\
\hline Butane + Propane ${ }^{\mathrm{c}}$ & 36.2 \\
\hline $\mathrm{CO}^{\mathrm{c}}$ & $2,402.0$ \\
\hline Ethane $^{c}$ & 27.7 \\
\hline Ethene $^{\mathrm{c}}$ & 40.5 \\
\hline Formaldehyde $^{a}$ & 8.2 \\
\hline Ketones $^{\mathrm{a}}$ & 8.4 \\
\hline $\mathrm{NH}_{3}{ }^{\mathrm{d}}$ & 145.8 \\
\hline $\mathrm{NO}^{\mathrm{c}}$ & 139.0 \\
\hline $\mathrm{NO}_{2}{ }^{\mathrm{c}}$ & 8.9 \\
\hline Propene $^{c}$ & 18.7 \\
\hline $\mathrm{SO}_{2}{ }^{\mathrm{e}}$ & 39.8 \\
\hline $\mathrm{SO}_{4}^{2-\mathrm{e}}$ & 2.5 \\
\hline Toluene $^{\mathrm{c}}$ & 22.1 \\
\hline Xylene $^{c}$ & 15.3 \\
\hline \multicolumn{2}{|c|}{$\begin{array}{l}\text { a EDGAR V2.0; benchmark year } 1990 \\
\text { b GEIA original inventory; benchmark year 1985; Penner et al. } \\
\text { (1993); Dignon et al. (1994) } \\
\text { cRETRO } \\
\text { d EDGAR V2.0; benchmark year 1990; Bouwman et al. (1997) } \\
{ }^{\text {e}} \text { GEIA original inventory; benchmark year 1985; Benkovitz et al. } \\
(1996) \\
{ }^{\text {f} H e x a n e ~ a n d ~ h i g h e r ~} \\
\text { gExcluding benzene, toluene, xylene, methyl benzene, and } \\
\text { trimethyl benzene }\end{array}$} \\
\hline
\end{tabular}


Emissions Inventory Activity (GEIA) website (GEIA 2006). Data was included from the RETRO emission database (Schultz 2007) and the EDGAR V2.0 emission database (Olivier et al. 1996; Bouwman et al. 1997). Multiple emission inventories were combined to include as many trace species as possible in the simulations. The RETRO emissions are available as monthly data in $0.5^{\circ}$ resolution. In the RETRO emissions, a discontinuity occurs at the equator due to the change in the seasons between the northern and southern hemispheres. As the equator is significant in the domain of these model experiments, the RETRO emissions for the southern hemisphere have been applied with the northern hemisphere seasonal cycle to avoid this discontinuity. The data provided from the other sources are available as annual means for the year 1985 or 1990 in $1.0^{\circ}$ resolution and have been interpolated to $0.5^{\circ}$ for the experiments. The Indonesian anthropogenic emissions range from $1-6 \%$ of the global total of anthropogenic emissions.

\section{Fire emissions}

The fire emission inventory (Table 2) is from the RETRO emission database (Schultz et al. 2008) and are provided as monthly data in $0.5^{\circ}$ resolution. The species included within the anthropogenic and fire inventories

Table 2 Indonesian Fire Emissions for September-November 1997

\begin{tabular}{|c|c|c|c|}
\hline Species & $\begin{array}{l}\text { Emissions } \\
\text { Gg } \\
\text { Sep. } 1997\end{array}$ & $\begin{array}{l}\text { Emissions } \\
\text { Gg } \\
\text { Oct. } 1997\end{array}$ & $\begin{array}{l}\text { Emissions } \\
\frac{\mathrm{Gg}}{\text { Nov. } 1997}\end{array}$ \\
\hline Acetaldehyde & $1,608.1$ & $1,329.3$ & 448.0 \\
\hline Black carbon & 355.4 & 266.2 & 89.8 \\
\hline Formaldehyde & $1,151.0$ & 913.6 & 307.9 \\
\hline $\mathrm{CO}$ & $134,708.3$ & $108,791.7$ & $36,662.5$ \\
\hline Ethane & 887.1 & 689.7 & 232.0 \\
\hline Ethene & $1,994.8$ & $1,589.8$ & 535.4 \\
\hline Isoprene & 544.5 & 461.1 & 155.4 \\
\hline Ketones $^{\text {a }}$ & 940.4 & 760.6 & 256.4 \\
\hline $\mathrm{NH}_{3}$ & $8,408.3$ & $7,065.5$ & $2,380.7$ \\
\hline $\mathrm{NO}_{2}$ & 82.6 & 63.9 & 21.6 \\
\hline $\mathrm{NO}$ & $1,293.5$ & 999.6 & 338.1 \\
\hline Organic carbon & $5,006.8$ & $3,970.4$ & $1,338.0$ \\
\hline Propane & 629.2 & 479.7 & 161.1 \\
\hline Propene & $2,010.3$ & $1,634.4$ & 550.2 \\
\hline $\mathrm{SO}_{2}$ & $1,960.2$ & $1,634.0$ & 550.6 \\
\hline $\mathrm{SO}_{4}^{2-}$ & 122.5 & 102.1 & 34.4 \\
\hline Toluene & 730.3 & 606.4 & 204.3 \\
\hline TPM & $24,790.8$ & $20,572.5$ & $6,935.7$ \\
\hline Xylene & 69.2 & 55.6 & 18.7 \\
\hline
\end{tabular}

All emissions from RETRO

${ }^{\text {a Acetone }}$ differ in that the fire emissions do not include higher alkanes or butane (which are oxidized in fires very quickly) while the anthropogenic emissions do not include isoprene (which is mainly emitted by vegetation), OC, or total particulate matter (TPM). All of the fire emission species increase dramatically in the dry season (northern hemisphere autumn) compared with the wet season (northern hemisphere spring). In September (the peak month of fire emissions), these emissions range from $62-95 \%$ of the global total of fire emissions. The Indonesian fires of 1997 are the largest contributor to global fire emissions contained in the RETRO wildland fire database (Schultz et al. 2008). The burning of peat during the fires contributed greatly to the severity of the emissions (auxiliary material Schultz et al. 2008).

\section{Volcanic emissions}

The amount of $\mathrm{SO}_{2}$ released by a volcano is dependent on many factors including activity type and varies widely from one volcano to another and at one volcano over time. There are few reported measurements of the degassing rates of the Indonesian volcanoes. The $\mathrm{SO}_{2}$ flux of five mildly erupting and passively degassing Indonesian volcanoes have been measured using correlation spectroscopy (COSPEC). Potentially stratosphere-reaching eruptive plumes have been observed with TOMS for four volcanoes and of tropospheric eruptions for two others. The petrologic method (whereby the difference in volatile concentration in melt inclusions and coexisting matrix glass is used to estimate degassing for one eruptive event) has been used to calculate the $\mathrm{SO}_{2}$ emissions of four large eruptions. Relatively rare stratospheric-reaching eruptions released from $200-5,800 \mathrm{Gg} \mathrm{SO}_{2}$ per eruption, while passive degassing and small eruptions (the source of most volcanic emissions) released from 5$240 \mathrm{Gg} \mathrm{SO}_{2}$ year $^{-1}$.

Because of the very few measurements of the emission rates of the Indonesian volcanoes, estimates are necessary to be able to incorporate volcanic emissions into modeling studies. A conservative emission estimate has been developed considering eruptive and passive degassing volcanic activity. The only volcanic species considered are $\mathrm{SO}_{2}$ and its oxidation product $\mathrm{SO}_{4}^{2-}$ because there is far more information available about the flux rate of $\mathrm{SO}_{2}$ at individual volcanoes at specific times and, more generally, at volcanoes at different activity levels than for any other species.

The eruptive activity recorded in the Simkin and Siebert (1994) catalog during the past century (19001993) for each volcano in the model domain were summed. Over this time period, 63 volcanoes in 
Table 3 Estimates of Indonesian volcanic emissions

\begin{tabular}{llll}
\hline & \multicolumn{3}{l}{ Emissions $\left(\mathrm{Gg}\left(\mathrm{SO}_{2}\right)\right.$ year $)$} \\
\cline { 2 - 4 } Author & Eruptive & Non-eruptive & Combined \\
\hline Hilton et al. (2002) & - & 120 & - \\
Spiro et al. (1992) & - & 210 & - \\
Nho et al. (1996) & 1,900 & 1,600 & 3,500 \\
Halmer et al. (2002) & - & - & $2,100-2,600$ \\
Pfeffer et al. (2006) & 290 & 3,500 & 3,790 \\
This study & 290 & 194 & 484 \\
\hline
\end{tabular}

Indonesia are known to have erupted and 32 additional volcanoes have passively degassed. The strength of each eruption as described by the volcanic explosivity index (VEI; Newhall and Self 1982) was used to calculate the amount of $\mathrm{SO}_{2}$ released following the volcanic sulfur index (VSI; Schnetzler et al. 1997). The total number of eruptions of each VEI class was multiplied by the maximum amount of $\mathrm{SO}_{2}$ released by arc volcanoes (volcanism produced by subduction) suggested by the VSI. The $\mathrm{SO}_{2}$ flux resulting from this multiplication was then divided by the 94 years of the record to generate an annual mean emission estimate. The time-averaging removes some of the high natural short-term variability in volcanic eruption frequency. These calculations indicate $290 \mathrm{Gg} \mathrm{SO}_{2}$ year $^{-1}$ released eruptively by the Indonesian volcanoes.

The passive emissions were calculated by assuming that $60 \%$ of volcanic emissions are eruptive and $40 \%$ are passive, following Halmer et al. (2002). This results in an assessment of $190 \mathrm{Gg} \mathrm{SO}_{2}$ year $^{-1}$ released passively. The passive emissions were divided evenly among the 95 active volcanoes, providing a mean passive $\mathrm{SO}_{2}$ flux of $2 \mathrm{Gg} \mathrm{SO}_{2}$ year $^{-1}$ for each volcano. The sum of passive and eruptive volcanic emissions is about $480 \mathrm{Gg} \mathrm{SO}_{2}$ year $^{-1}$.

The estimated emissions of individual volcanoes are generally less than COSPEC measurements. The COSPEC measurements were mostly made during times of tropospheric eruptive activity and eruptions
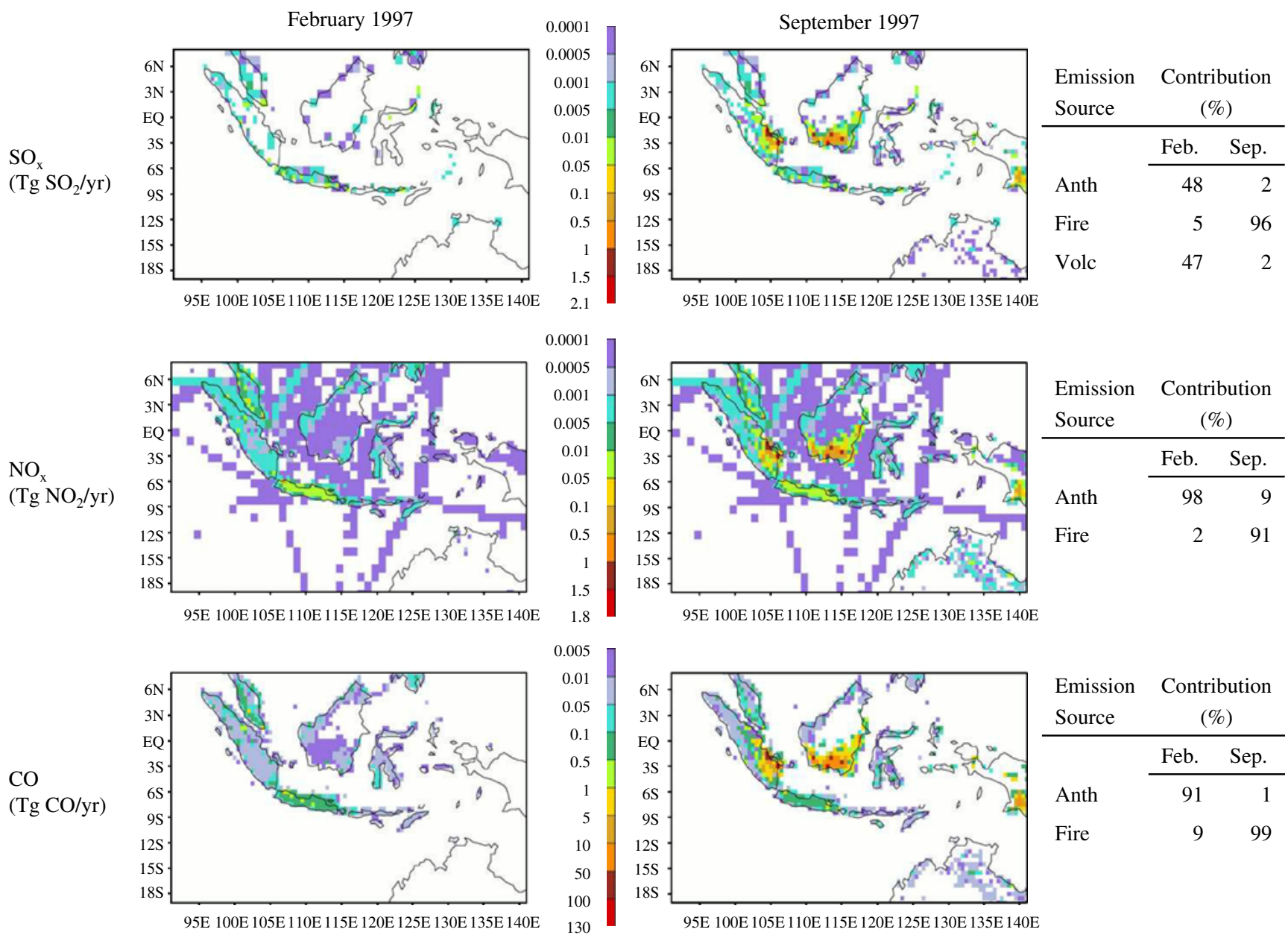

Fig. 1 Total emissions for the sum of the anthropogenic, fire, and volcanic sources for $\mathrm{SO}_{x}, \mathrm{NO}_{x}$, and $\mathrm{CO}$ for February and September 1997 
are frequently interspersed with long periods of passive degassing. The lower values of the estimated emissions compared with the COSPEC measurements reflect this lower emission flux averaged over time. We contend that this century-mean emission inventory provides a realistic, conservative estimate of the volcanic degassing of $\mathrm{SO}_{2}$ in the region (Table 3 ).

Implementation of emission inventories

Figure 1 shows the total emissions from anthropogenic, fire, and volcanic sources for $\mathrm{SO}_{x}\left(\mathrm{SO}_{2}+\mathrm{SO}_{4}^{2-}\right)$ and the total emissions from anthropogenic and fire sources for $\mathrm{NO}_{x}\left(\mathrm{NO}_{2}+\mathrm{NO}\right)$ and $\mathrm{CO}$ for February and September 1997. The emissions of each volcano have been released into the model layer at the height of the volcano, which lie within the bottom 12 model levels (up to about $4 \mathrm{~km}$ ). This is a practical approach as we do not have sufficient data to reasonably estimate the injection heights of the eruptive emissions or the amount of passive degassing from the flanks of the volcanoes. The anthropogenic and fire emissions were released into the bottom model layer, which is between $\sim 30-500 \mathrm{~m}$ thick. This is a reasonable approach for Indonesia where few industrial stack heights exceed this height and where most of the biomass burning emissions are from smoldering peat fires (Heil 2007). For all three species, the fire emissions strongly dominate in September while they are minor in February. Because of the severity of the fires, the total emissions are also greatly increased in September. The fires in September 1997 were strongest in southern Kalimantan and southeastern Sumatra.

\section{Experiments}

In order to ascertain the influence of the different emission sources within the model domain on the air quality in the region, an experiment including all emission sources and two sensitivity experiments excluding an
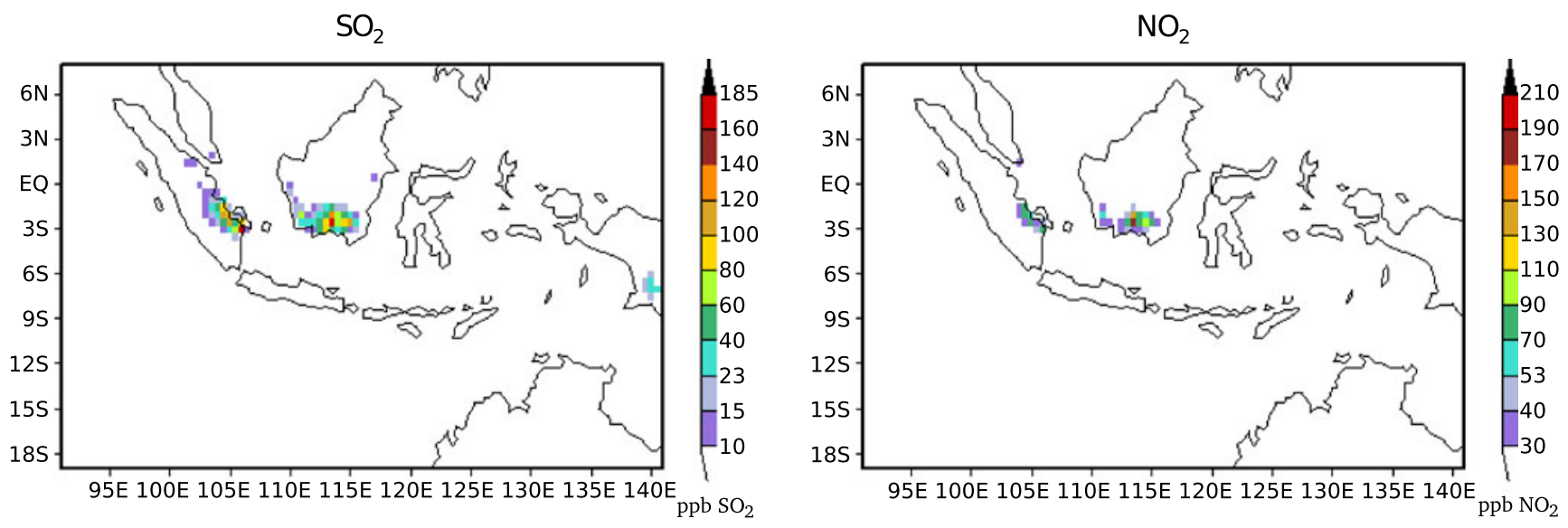

\section{$\mathrm{CO}$}

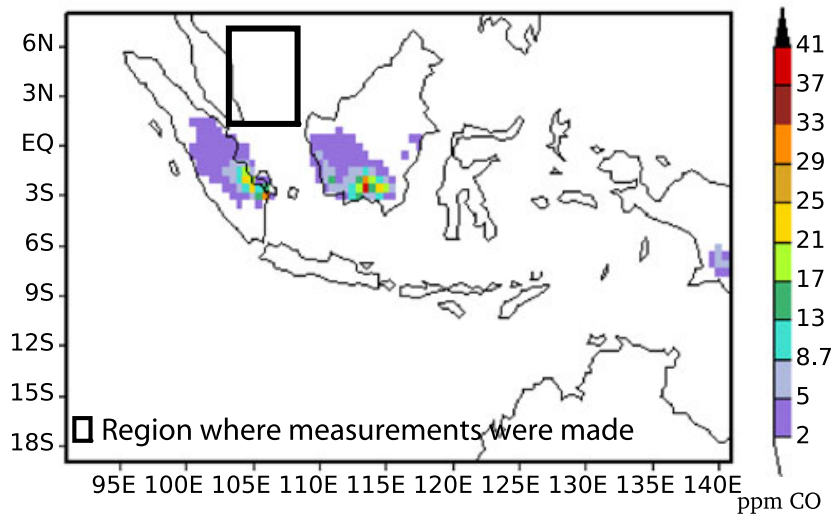

$\mathrm{O}_{3}$

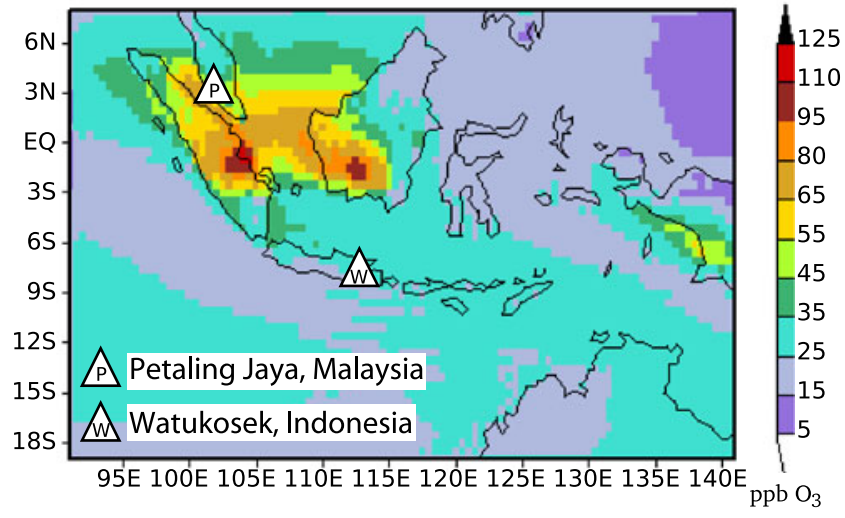

Fig. 2 Ground-level concentration of $\mathrm{SO}_{2}, \mathrm{NO}_{2}, \mathrm{CO}$, and $\mathrm{O}_{3}$ averaged over September-November 1997 for experiment AnthVolc-Fire 
emission source were conducted. (1) Anth-Volc-Fireemissions from the anthropogenic, volcanic, and fire sources were included in the model experiment: this is the reference experiment; (2) Volc-Fire-only emissions from the volcanic and fire sources were included while anthropogenic emissions inside the domain were excluded; and (3) Anth-Fire-only emissions from the anthropogenic and fire sources were included while volcanic sources inside the domain were excluded. In figures, experiments Anth-Volc-Fire, Volc-Fire, and Anth-Fire will be referred to as AVF, VF, and AF, respectively. All experiments were conducted for the year 1997. The sulfur species, $\mathrm{SO}_{2}$ and $\mathrm{SO}_{4}^{2-}$, have been "marked" into four categories: $A, V$, and $F$ for the anthropogenic, volcanic, and fire emission sources, respectively, and $B$ for the sulfur containing species defined at the boundaries of the simulation area. This marking allows sulfur from each source to be followed individually throughout the experiments as four $\mathrm{SO}_{2}$ and four $\mathrm{SO}_{4}^{2-}$ tracers. This is a technique only possible in modeling studies.

\section{Results}

The maximum surface concentrations of $\mathrm{SO}_{2}, \mathrm{NO}_{2}$, $\mathrm{CO}$, and $\mathrm{O}_{3}$ in September-November 1997 are found
Table 4 Indonesian air quality standards

\begin{tabular}{llrc}
\hline Pollutant & $\begin{array}{l}\text { Averaging } \\
\text { time }\end{array}$ & \multicolumn{2}{c}{ Standard } \\
\cline { 3 - 4 } & $1 \mathrm{~h}$ & 900 & $\mathrm{ppm}^{\mathrm{a}}$ \\
\hline $\mathrm{SO}_{2}$ & $24 \mathrm{~h}$ & 365 & 0.34 \\
& $1 \mathrm{year}$ & 100 & 0.14 \\
& $1 \mathrm{~h}$ & 400 & 0.023 \\
$\mathrm{NO}_{2}$ & $24 \mathrm{~h}$ & 150 & 0.21 \\
& 1 year & 100 & 0.080 \\
& $1 \mathrm{~h}$ & 30,000 & 0.053 \\
$\mathrm{CO}$ & $24 \mathrm{~h}$ & 10,000 & 26.2 \\
& $1 \mathrm{~h}$ & 235 & 8.7 \\
$\mathrm{O}_{3}$ & $1-$ year & 50 & 0.12 \\
& & &
\end{tabular}

Syahril et al. (2002); For comparison, the air quality standards of the US EPA (ppm) are: $\mathrm{SO}_{2} 24 \mathrm{~h}, 0.14 ; \mathrm{NO}_{2} 1$ year, 0.053; CO $1 \mathrm{~h}, 35 ; \mathrm{O}_{3} 8 \mathrm{~h}, 0.08$

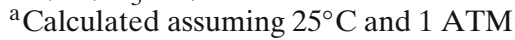

over southeastern Sumatra and southern Kalimantan (Fig. 2): the locations of the most intense fires. These four compounds are focused on because they are among the pollutants regulated by the Indonesian government and they are active participants in tropospheric chemistry. These 3 -month average values have been plotted to highlight where they exceed the Indonesian air quality standards. There are no 3-month air quality standards (Table 4). There are 1-year air quality standards for $\mathrm{SO}_{2}(0.023 \mathrm{ppm})$,
Fig. 3 Vertical profiles of the modeled (filled triangles) and measured (open circles) $\mathrm{O}_{3}$ for 17 February, 15 September, 15 October, and 17 November 1997 at Petaling Jaya, Malaysia $\left(3.0^{\circ} \mathrm{N}, 101.5^{\circ} \mathrm{E}\right)$.

Measurements are from Yonemura et al. (2002a)

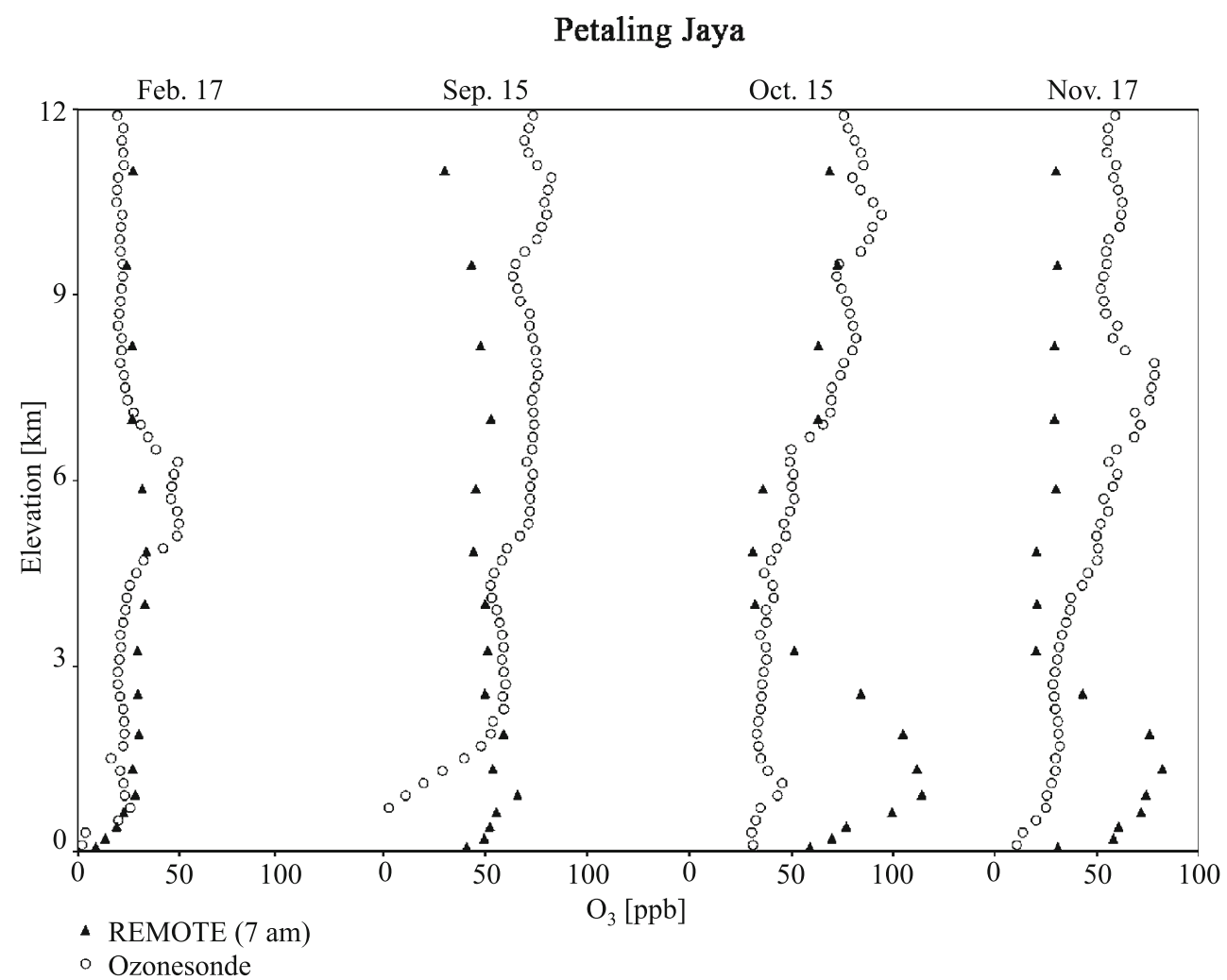


Fig. 4 Vertical profiles of the modeled (filled triangles) and measured (open circles) $\mathrm{O}_{3}$ for 19 February, 17 September, 15 October, and 19 November 1997 at Watukosek, Indonesia $\left(7.5^{\circ} \mathrm{S}, 112.6^{\circ} \mathrm{E}\right)$.

Measurements are from Fujiwara et al. (1999)

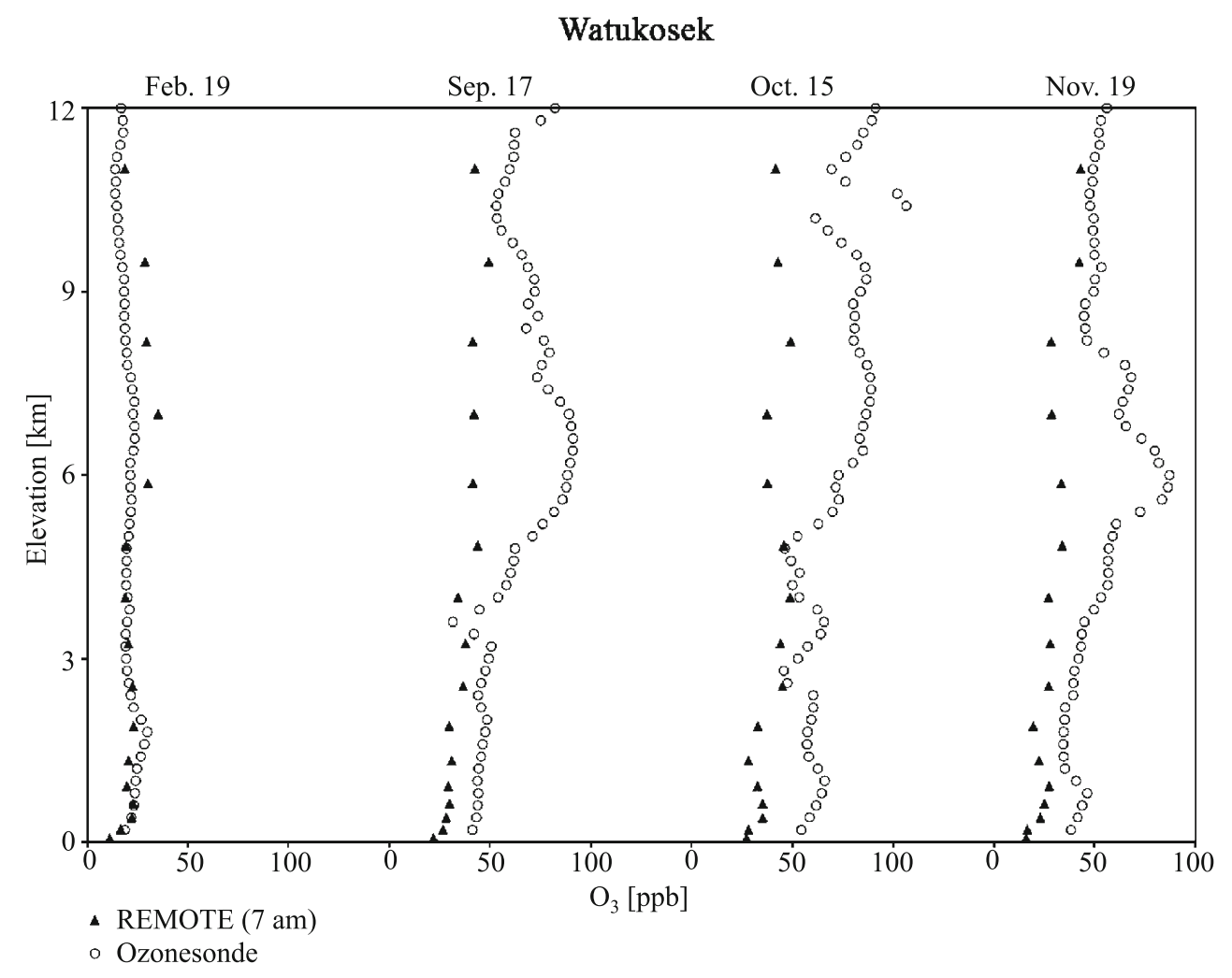

$\mathrm{NO}_{2}(0.053 \mathrm{ppm})$, and $\mathrm{O}_{3}(0.025 \mathrm{ppm})$ and a $24-\mathrm{h}$ standard for $\mathrm{CO}(8.7 \mathrm{ppm})$. Comparing the 3-month average values of $\mathrm{SO}_{2}, \mathrm{NO}_{2}$, and $\mathrm{O}_{3}$ with the 1-year standards will overestimate the region where the air quality standards were exceeded, as the fires did not last a whole year. Comparing the 3-month average value of $\mathrm{CO}$ with the 24-h standard will produce an underestimation of the region with exceedances. Despite the lack of 3-month air quality standards, comparing these three months of the main fires with the longest available air quality standards provides a framework to consider the severity of the pollution. Regions in Fig. 2 that exceed the standards as described above are plotted in green through red, while regions with concentrations less than the standards are plotted in white and blue. $\mathrm{SO}_{2}$, $\mathrm{NO}_{2}$, and $\mathrm{CO}$ rarely exceed the air quality standards.

Fig. 5 Vertical profiles of the modeled (filled triangles) and measured (open circles) CO for 20 October 1997 between $1-7^{\circ} \mathrm{N}$ and $103-109^{\circ}$ E. Measurements were made using a gas chromatograph equipped with a flame ionization detector (GC/FID) from Matsueda and Inoue (1999)

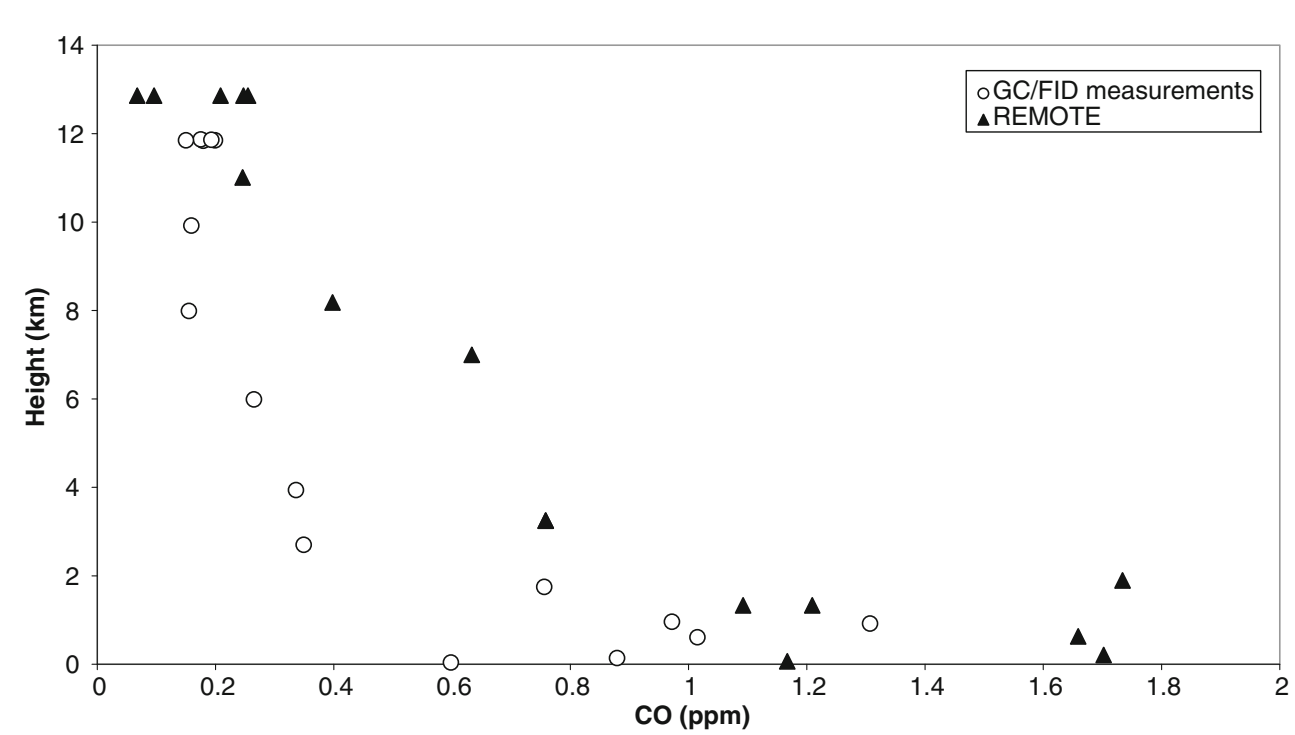


The three-month averaged $\mathrm{O}_{3}$ exceeds the 1-year air quality standard over a large portion of the modeling domain, most significantly extending from the fires northwestward over much of western Kalimantan, central Sumatra, and southern Malaysia.

The modeled $\mathrm{O}_{3}$ has been compared with ozonesonde measurements performed at two locations: Petaling Jaya, Malaysia (Fig. 3; Yonemura et al. 2002a) and Watukosek, Indonesia (Fig. 4; Fujiwara et al. 1999; for locations of measurements see bottom right panel of Fig. 2). At Petaling Jaya, 23 ozonesonde measurements were performed in 1997, typically at the beginning/end of a month and in the middle of a month, usually around 20:00 (local time). At Watukosek, 20 measurements were made, similarly at the beginning/end of a month and in the middle of a month, with no measurements made April-June and weekly measurements made October-December, usually around 10:00 (local time).

Petaling Jaya is downwind of the fires and is modeled to be affected by the fire-related $\mathrm{O}_{3}$, with surface concentrations greater than the 1-year air quality standard. In February, the simulated $\mathrm{O}_{3}$ matches the measured very well. During the three months of the fire, the model overpredicts the surface $\mathrm{O}_{3}$ at Petaling Jaya by $20-40 \mathrm{ppb}$. Between 1-2 km elevation, the model greatly overpredicts the $\mathrm{O}_{3}$ and becomes less than the observed above $3 \mathrm{~km}$. Watukosek is upwind of the fires, and the measured $\mathrm{O}_{3}$ is greater than the $\mathrm{O}_{3}$ measured at Petaling Jaya. Again, the modeled $\mathrm{O}_{3}$ in February matches the observation very well. For the three months of the fire, the simulated $\mathrm{O}_{3}$ is

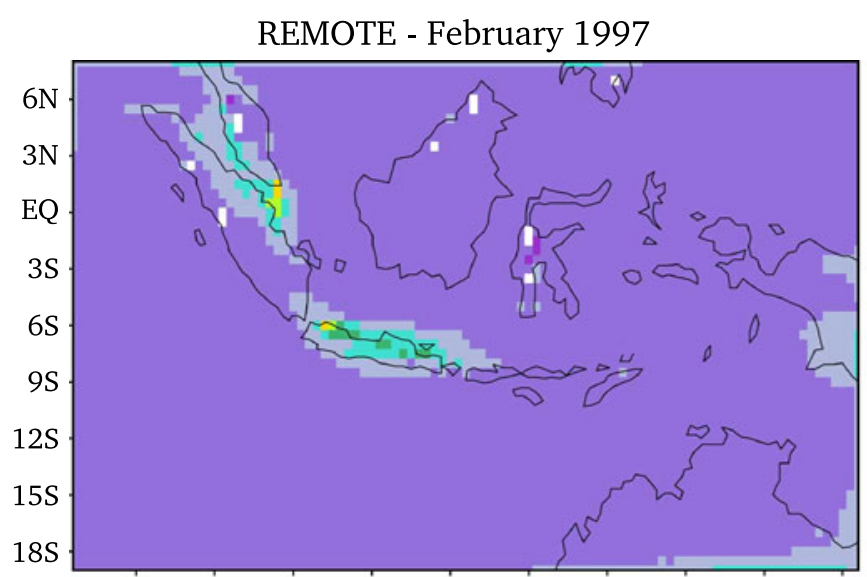

95E 100E 105E 110E 115E 120E 125E 130E 135E 140E REMOTE - September 1997

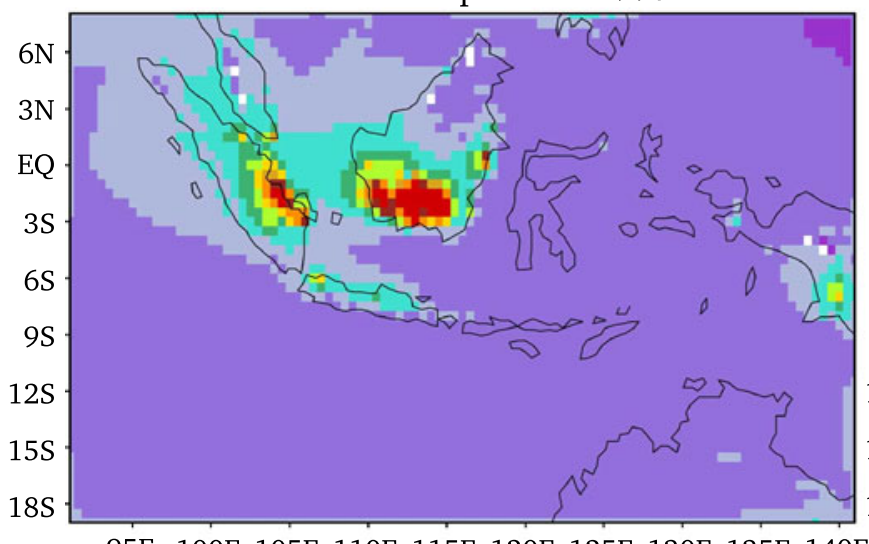

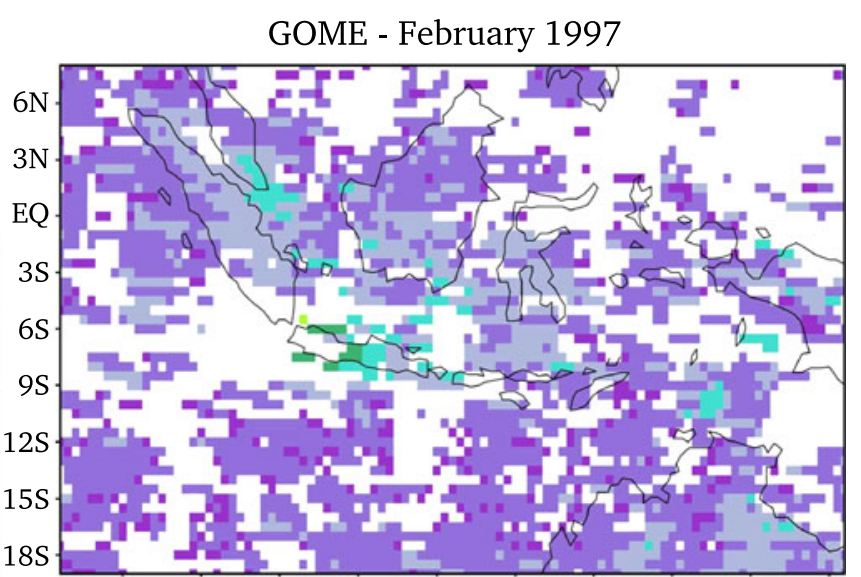

95E 100E 105E 110E 115E 120E 125E 130E 135E 140E

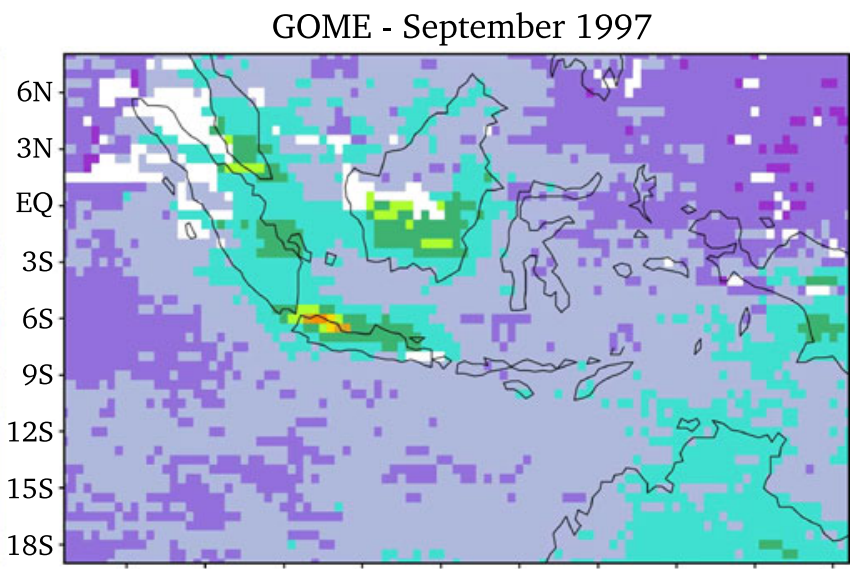

95E 100E 105E 110E 115E 120E 125E 130E 135E 140E

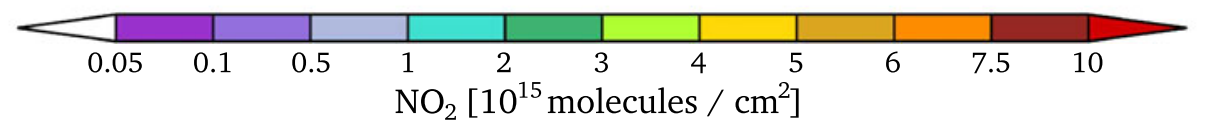

Fig. 6 Tropospheric column concentration of $\mathrm{NO}_{2}$ for February (top row) and September (bottom row) 1997 for REMOTE model simulations (left column) and GOME satellite observations (right column; Richter et al. 2005) 
less than the observed and up to $3 \mathrm{~km}$ matches the vertical pattern of the ozonesonde measurements quite well. The modeled $\mathrm{CO}$ has been compared with airborne measurements made on October 20, 2007 (Fig. 5; Matsueda and Inoue 1999; for locations of measurements see bottom left panel of Fig. 2). The model results shown are for the horizontal grid box and model level containing the latitude/longitude and elevation where a sample was collected. Heights of the measurements and model results are not equal in the figure because the model results are presented at the mean height of the model layer. The modeled CO is approximately double the observed throughout the vertical profile, and replicates the vertical trend very well.

The modeled, monthly averaged $\mathrm{NO}_{2}$ tropospheric column concentration for February and September 1997 has been compared with gridded, monthly averaged GOME satellite data (Fig. 6; Richter et al. 2005). Despite the missing data in the February 1997 GOME image (the white pixels), it can be seen that the REMOTE February simulation matches the GOME image well. In September 1997, the burning regions of southern Kalimantan and southeastern Sumatra have much greater $\mathrm{NO}_{2}$ burdens than the GOME image shows. The modeled $\mathrm{O}_{3}$ tropospheric column concentration cannot be compared with GOME observations, because REMOTE does not include stratospheric chemistry. A result of this is that the very important transport of $\mathrm{O}_{3}$ from the stratosphere into the troposphere is not captured, and our simulated tropospheric column concentrations will necessarily be underestimated.

The influence of the anthropogenic emissions in the domain has been depicted by subtracting the surface concentration of the four species of interest calculated in the experiment without anthropogenic emissions (Volc-Fire) from the results of the reference experiment (Anth-Volc-Fire; Fig. 7). The anthropogenic surface concentrations (Fig. 7) are about one order of magnitude less than the total surface concentrations (Fig. 2). The greatest increase of $\mathrm{SO}_{2}$ and $\mathrm{NO}_{2}$ is found above Singapore, with an increase of $91 \%$

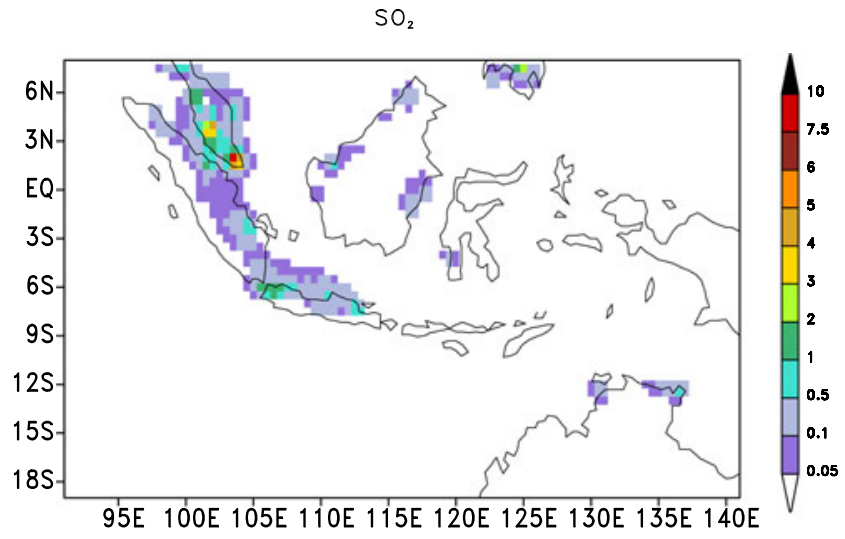

$\mathrm{Ppb} \mathrm{SO}_{2}$

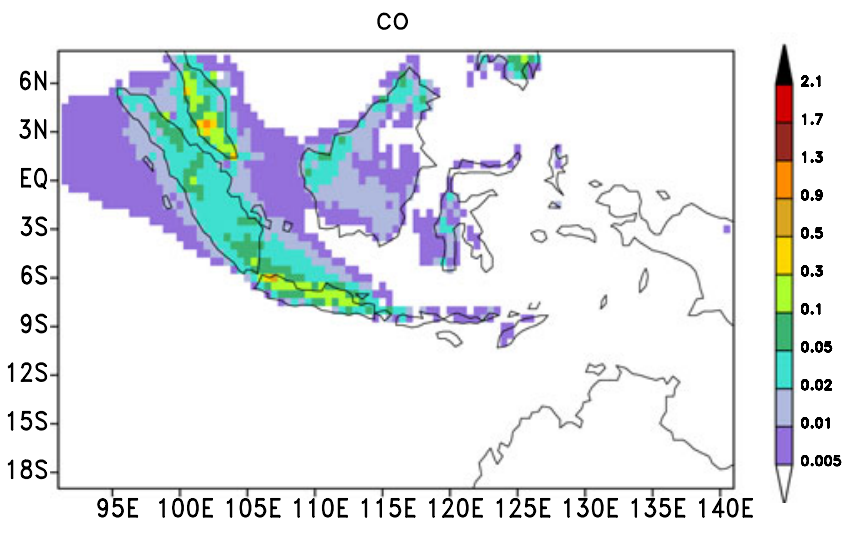

ppm CO
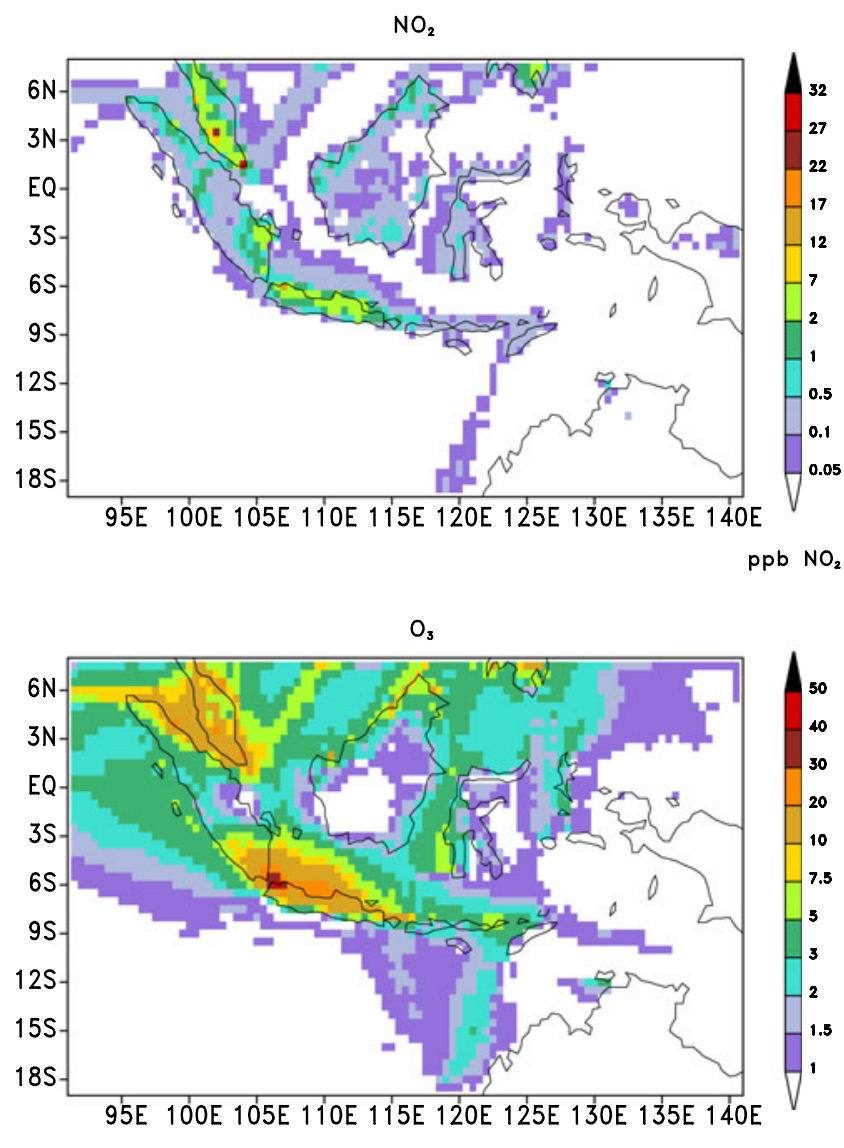

$\mathrm{ppb} \mathrm{O}_{3}$

Fig. 7 Difference in surface concentration of $\mathrm{SO}_{2}, \mathrm{NO}_{2}, \mathrm{CO}$, and $\mathrm{O}_{3}$ averaged over September-November 1997 for experiment AnthVolc-Fire-Volc-Fire 
for $\mathrm{SO}_{2}$ and $99 \%$ for $\mathrm{NO}_{2}$ when the anthropogenic emissions are included in the experiments. The greatest effect for $\mathrm{CO}$ is above Kuala Lumpur, where the anthropogenic emissions increase the atmospheric $\mathrm{CO}$ by $58 \%$ and for $\mathrm{O}_{3}$ above Jakarta by $67 \% . \mathrm{O}_{3}$ is not enhanced by the anthropogenic pollution over most of Kalimantan and southeastern Sumatra, where the emissions from the fires were the strongest. The influence of the volcanic emissions on these four species has been calculated accordingly, by subtracting the results of the experiment without volcanic emissions (AnthFire) from Anth-Volc-Fire. These results are not shown because the influence on $\mathrm{SO}_{2}$ is minor, with the volcanic emissions contributing primarily over Java.

\section{Discussion}

The observational data set is too small to make a robust statistical comparison with the model results: it is only possible to present a visual comparison of the model results with the few observations. Comparisons of the model results with the measurement sets available indicate that the simulated atmospheric concentrations of trace gases from the fires are too high at downwind locations. $\mathrm{O}_{3}$ compared with ozonesonde measurements at Petaling Jaya, CO compared with airborne measurements made slightly beyond the region where the model simulates the fire emissions to have been transported, and $\mathrm{NO}_{2}$ as observed by GOME all support this. In contrast, comparisons made in February, not during the extreme fires, agree well. We do not put as much weight on the comparison with measurements made at Watukosek. It is possible that the $\mathrm{O}_{3}$ values measured at Watukosek are too high, as they are greater than the values measured at Petaling Jaya (downwind of the fires) and the high values continue after the end of the fires. Ladstätter-Weißenmayer et al. (2005) show that the tropospheric column concentration of $\mathrm{O}_{3}$ as calculated from the ozonesonde measurements at Watukosek in September 1997 are about 10 DU greater than the GOME satellite observations. Thompson et al. (2003) offer the hypothesis that half of the tropospheric $\mathrm{O}_{3}$ increase measured at Watukosek may be due to large scale dynamical processes rather than fire emission related photochemical processes, in which case the measurements may not be too high, rather there is a physical transport mechanism that is not being correctly simulated.

The RETRO fire trace gas emissions included in this study may be overestimated. The RETRO fire emissions can be most readily compared with the
Global Fire Emissions Database, Version 2 (GFEDv2; Randerson et al. 2006). RETRO has higher emissions than GFEDv2, which is attributed to a greater contribution from smoldering peat fires (auxiliary material Schultz et al. 2008). The RETRO emissions for the 1997 Indonesian fires has an uncertainty range of at least a factor of four due to uncertainties in variables including biomass load and burning efficiency (Heil 2007). Unfortunately, given the paucity of measurement data, it is not possible using the comparisons we have made to quantify the possible overestimation. Given that the fire emissions may be too high, the results regarding the air quality exceedances are most likely overestimated. The good performance of the model's atmospheric chemistry in February, outside of the burning season, suggests that the results relating to the interactions between the different emission sources may be valuable. If the fire emissions have been overestimated, however, this will influence the results relating to the other emission sources, and as such the results presented are for this one simulated scenario.

A detailed comparison of the model's simulated rainfall with data from the Global Precipitation Climatology Centre (GPCC 2007), Global Precipitation Climatology Project (Huffman et al. 1997), and individual Malaysian stations is presented in Langmann and Heil (2004). The relevant comparison is for the so-called climate mode. It is shown that the REMOTE model follows the seasonal trend of dry season/wet season very well but strongly overestimates rainfall, particularly over the ocean. Over land, REMOTE's simulation of rainfall is more reasonable. This overprediction means that water soluble compounds, such as $\mathrm{SO}_{4}^{2-}$, will be washed out of the atmosphere too quickly but will have little effect on less soluble compounds.

The highest surface concentrations of $\mathrm{SO}_{2}, \mathrm{NO}_{2}$, $\mathrm{CO}$, and $\mathrm{O}_{3}$ in September-November 1997 were modeled to be directly above southeastern Sumatra and southern Kalimantan-the locations of the strongest fires, with winds out of the southeast transporting the pollution. The active Indonesian volcanoes are upwind of the fires. They contributed only slightly to the surface concentration of $\mathrm{SO}_{2}$ during the fires and did not discernibly influence the concentration of the secondary pollutant $\mathrm{O}_{3}$. The anthropogenic pollution was greatest above the major cities in the region: Jakarta, Singapore, and Kuala Lumpur. Singapore and Kuala Lumpur are in the downwind path of the fire pollution, while Jakarta is upwind. The modeled concentrations of $\mathrm{SO}_{2}, \mathrm{NO}_{2}$, and $\mathrm{CO}$ were all highest at 7:00 (local time) as the pollutants are trapped in the nocturnal boundary layer. The modeled concentration of $\mathrm{O}_{3}$ was highest at 13:00 (local time) due to photochemical reactions. 
The 1-h air quality standards (Table 4) were exceeded for all four species at discrete modeled hourly values above and downwind of the main fires. For $\mathrm{SO}_{2}, \mathrm{NO}_{2}$, and $\mathrm{CO}$ the exclusion of the anthropogenic pollution in the domain (experiment Anth-Volc-FireVolc-Fire) produces a minor reduction in the number of exceedances at 7:00. The inclusion of the anthropogenic pollution increases the total sum of $\mathrm{O}_{3} 1$-h exceedances where the most people live (Fig. 8). Applying the Gridded Population of the World Version 3 (GPWv3) data for the year 1995 (Center for International Earth Science Information Network (CIESIN), Columbia University and Centro Internacional de Agricultura Tropical (CIAT) 2005) indicates an increase of $17 \%$ of the number of people living in grid boxes with 1-h $\mathrm{O}_{3}$ exceedances. Some of the changes in surface $\mathrm{O}_{3}$ due to anthropogenic emissions are due to $\mathrm{NO}_{x}$ pollution along the lines of international shipping (bottom right panel Fig. 7; middle row Fig. 1).

It is shown by subtracting the $\mathrm{SO}_{2} F$ (the $\mathrm{SO}_{2}$ marked as specifically fire) in experiment Volc-Fire from that in Anth-Volc-Fire (top row Fig. 9) that the difference in $\mathrm{SO}_{2} F$ is negative over peninsular Malaysia and Java, near the large cities where the anthropogenic emissions are strongest, and positive above the southeastern Sumatra fires. The difference in $\mathrm{SO}_{4}^{2-} F$ shows the reverse pattern: where the difference in $\mathrm{SO}_{2} F$ is negative, that in $\mathrm{SO}_{4}^{2-} F$ is positive. The anthropogenic emissions in the domain enhance the conversion of the $\mathrm{SO}_{2}$ released by the fires to $\mathrm{SO}_{4}^{2-}$. This decrease in $\mathrm{SO}_{2} F$ is in contrast to the upper left panel in Fig. 7 which shows an increase in the total $\mathrm{SO}_{2}$. While the anthropogenic emissions decrease $\mathrm{SO}_{2} F$, the total $\mathrm{SO}_{2}$ is increased. The decrease in $\mathrm{SO}_{2} F$ occurs in the same areas as where the anthropogenic emissions have increased the surface concentration of $\mathrm{O}_{3}$ (bottom right panel of Fig. 7). The increase of $\mathrm{O}_{3}$ by the anthropogenic emissions leads to the enhancement of the conversion of $\mathrm{SO}_{2}$ to $\mathrm{SO}_{4}^{2-}$. The evidence that the secondarily produced compound $\mathrm{O}_{3}$ influences another secondarily produced compound, $\mathrm{SO}_{4}^{2-}$, shows that the anthropogenic emissions are able to change the atmospheric lifetime of the fire pollution. This is a demonstration of non-linearity in the chemical system.

As we looked at $\mathrm{SO}_{2} F$ to see how the anthropogenic pollution affected the fire emissions, we have looked at $\mathrm{SO}_{2} A$ to examine the influence of the fire emissions on the anthropogenic. The subtraction of $\mathrm{SO}_{2} A$ in experiment Anth-Volc from that in Anth-Volc-Fire (bottom row Fig. 9) shows that the difference in $\mathrm{SO}_{2} A$ is negative. The difference in $\mathrm{SO}_{4}^{2-} A$ is positive above the main fires and negative above peninsular Malaysia. The fire emissions are leading to the more rapid oxidation of $\mathrm{SO}_{2} A$ to $\mathrm{SO}_{4}^{2-} A$. Above peninsular Malaysia, the $\mathrm{SO}_{4}^{2-} A$ is then being formed in a region with more precipitation (not shown), leading to a more rapid wash out of the $\mathrm{SO}_{4}^{2-} A$, producing the negative difference in $\mathrm{SO}_{4}^{2-} A$.

The possibility that the anthropogenic emissions contributed to air quality exceedances caused primarily by the fire pollution, particularly in the vicinity of major cities, is relevant for the transboundary pollution issue. In Quah (2002), different approaches are discussed involving both Indonesia (the state where the fires occurred) and "victim states" including Singapore and Malaysia in fire prevention and fire reduction. All of the suggested mechanisms for reducing the firerelated haze events involve minimizing the fires within Indonesia. This is very important, and a clear, logical approach to prevent future environmental disasters
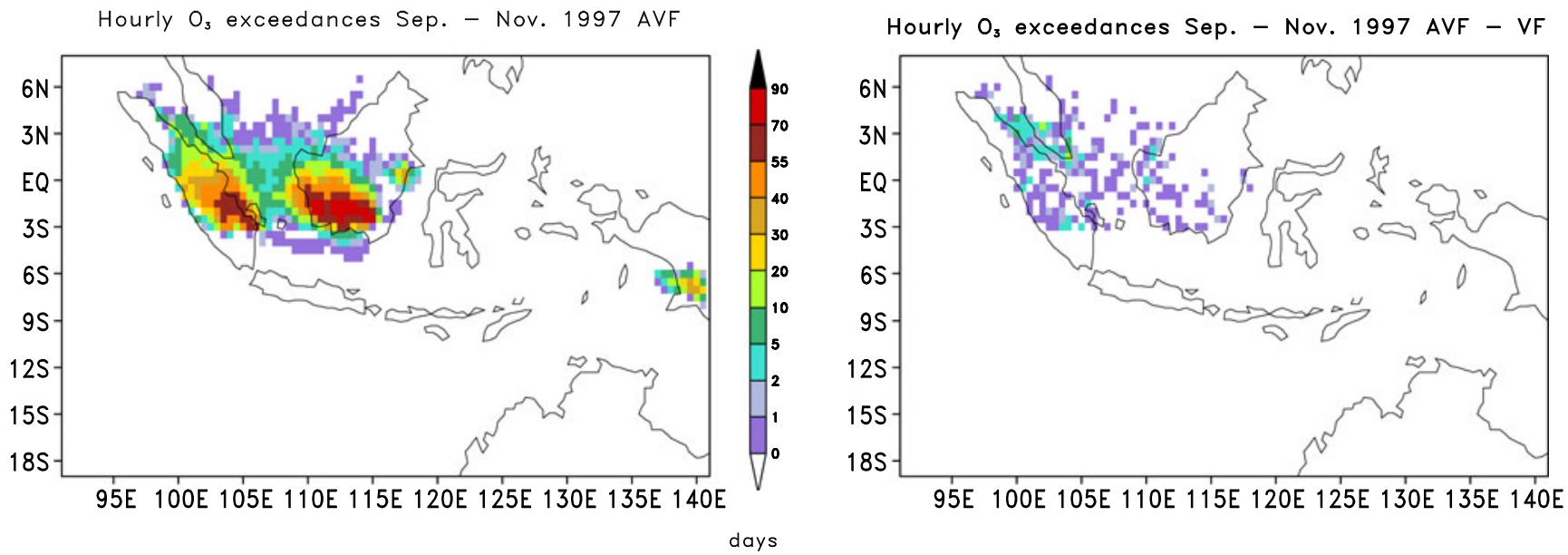

Fig. 8 The number of days during September-November 1997 when the Indonesian hourly air quality standard for $\mathrm{O}_{3}$ was exceeded at 13:00 for experiment Anth-Volc-Fire and the difference in Anth-Volc-Fire-Volc-Fire 

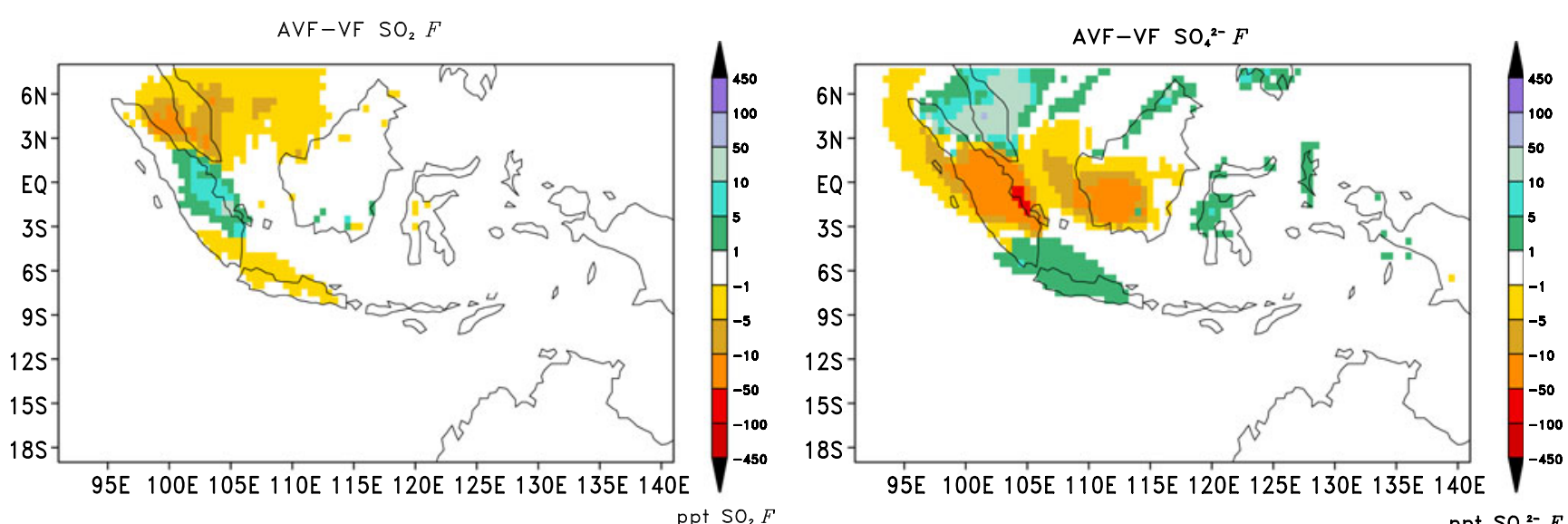

ppt $\mathrm{SO}_{2} \mathrm{~F}$

ppt $\mathrm{SO}_{4}^{2-} F$
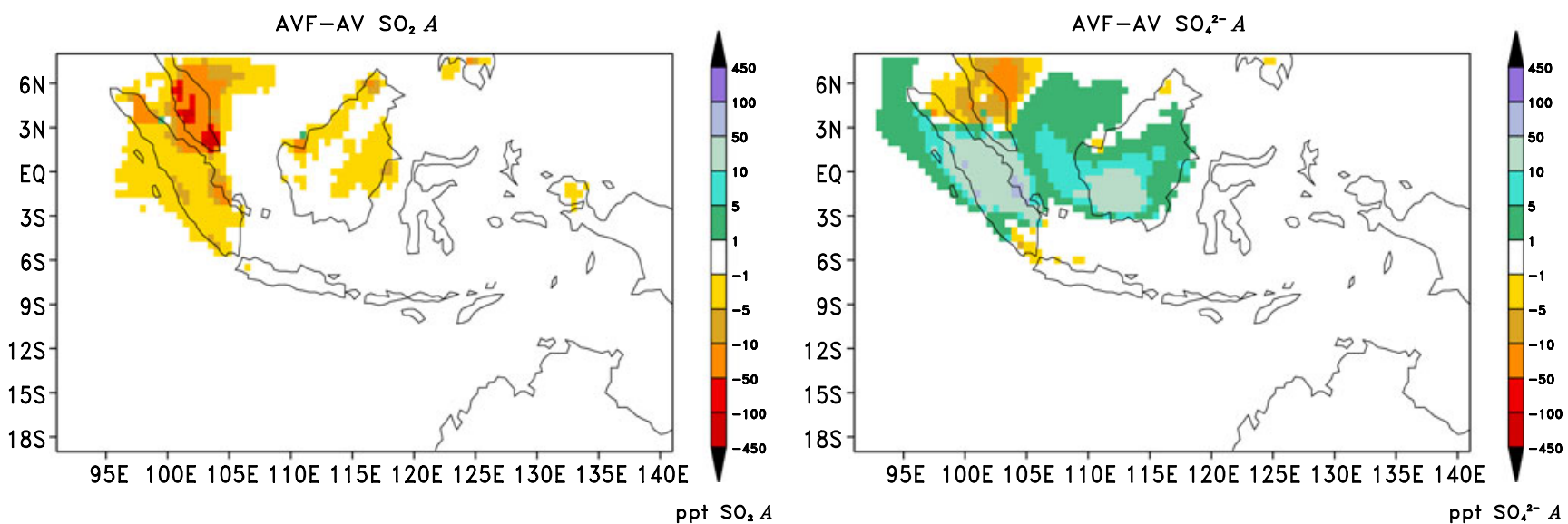

Fig. 9 Difference in the average ground level concentration for September 1997 of $\mathrm{SO}_{2} F$ and $\mathrm{SO}_{4}^{2-} F$ for experiments Anth-VolcFire-Volc-Fire (top row) and of $\mathrm{SO}_{2} A$ and $\mathrm{SO}_{4}^{2-} A$ for experiments Anth-Volc-Fire-Anth-Volc (bottom row)

such as occurred during the 1997 fires. The theoretical results of this study suggest an additional approach for neighboring countries that are adversely affected by the fire-related haze: reducing urban air pollution during high-risk times. This may have the effect of keeping the atmospheric concentrations of dangerous pollutants in densely populated areas below the air-quality thresholds, reducing the health and economic consequences of the fires in major cities. If the fire emissions included in the scenario presented here were overestimated, the number of modeled air quality exceedances is greater than really occurred. The role of the anthropogenic emissions in the domain relative to the fire, in that case, will be greater.

\section{Conclusions}

Indonesian air quality standards for $\mathrm{O}_{3}, \mathrm{SO}_{2}, \mathrm{CO}$, and $\mathrm{NO}_{2}$ were simulated to have been exceeded during the
Indonesian fires of 1997. Due to sparse ground and air based measurements at the time, these simulations represent one possible scenario, our best attempt to capture the complex interactions between various emissions sources during this very important event. Results from this modeled scenario suggest that the RETRO fire emissions included in this study may be overestimated. Anthropogenic emissions were modeled to have extended the region where air quality standard exceedances may have occurred, most significantly for the secondary pollutant $\mathrm{O}_{3}$ in densely populated urban areas. Because the range of possible fire emissions is so great, it is unlikely the modeled number of emission standard exceedances depict reality correctly. The model results show us that the increased atmospheric concentration of $\mathrm{O}_{3}$ from the anthropogenic emissions in the domain increased the rate of conversion of $\mathrm{SO}_{2}$ released by the fires to $\mathrm{SO}_{4}^{2-}$. This study distinguishing the roles of the different emission sources may help in creating solutions to reduce the harmful effects 
of wildfire pollution. Large cities downwind from major fire events may benefit by reducing their urban pollution during such events, thereby reducing health and economic disturbances. The surface conditions present during this extreme event led to volcanic emissions serving only a minor role.

\begin{abstract}
Acknowledgements We thank Philipp Weis and Elina Marmer for their help and discussion and Sebastian Rast, Álvaro Valdebenito, Julia Lee-Taylor, and two anonymous reviewers for reviewing the manuscript. We thank the German Climate Computing Center (DKRZ) and Johann Feichter for computer time to run these experiments and Ulrike Niemeier for providing the MOZART results that were used as boundary conditions. $\mathrm{O}_{3}$ measurements were kindly made available by Masatomo Fujiwara over Watukosek and by Seiichiro Yonemura over Petaling Jaya. CO measurements were made available by Hidekazu Matsueda. Andreas Richter and Mark Weber provided access to the GOME $\mathrm{NO}_{2}$ observations. Martin Schultz provided access to the RETRO emissions. M. Pfeffer was funded by the Ebelin and Gerd Bucerius ZEIT Foundation and by the American Association of University Women.
\end{abstract}

Open Access This article is distributed under the terms of the Creative Commons Attribution Noncommercial License which permits any noncommercial use, distribution, and reproduction in any medium, provided the original author(s) and source are credited.

\section{References}

Aiken S (2004) Runaway fires, smoke-haze pollution, and unnatural disasters in Indonesia. Geograph Rev 94(1):55-79

Benkovitz C, Scholtz M, Pacyna J, Tarrason L, Dignon J, Voldner E, Spiro P, Logan J, Graedel T (1996) Global gridded inventories of anthropogenic emissions of sulfur and nitrogen. J Geophys Res 101(D22):29239-29253

Bouwman A, Lee D, Asman W, Dentener F, Van Der Hoek K, Olivier J (1997) A global high-resolution emission inventory for ammonia. Gl Biogeochem Cycles 11(4):561-587

Burrows J, Weber M, Buchwitz M, Rozanov V, LadstätterWeissenmayer A, Richter A, DeBeek R, Hoogen R, Bramstedt K, Eichmann KU, Eisinger M, Perner D (1999) The global ozone monitoring experiment (GOME): mission concept and first scientific results. J Atmos Sci 56:151175

Center for International Earth Science Information Network (CIESIN), Columbia University and Centro Internacional de Agricultura Tropical (CIAT) (2005) Gridded population of the world version 3 (GPWv3): Population Grids, Tech. rep., Socioeconomic Data and Applications Center (SEDAC), Columbia University, Palisades, NY. Available at: http://sedac.ciesin.columbia.edu/gpw. Accessed November 2010

Chandra S, Ziemke J, Min W, Read W (1998) Effects of 19971998 El Niño on tropospheric ozone and water vapor. Geophys Res Lett 25(20):3867-3870

Chandra S, Ziemke J, Bhartia P, Martin R (2002) Tropical tropospheric ozone: implications for dynamics and bio- mass burning. J Geophys Res 107(D14):4188. doi:10.1029/ 2001JD000447

Chang JS, Brost RA, Isaksen SA, Madronich S, Middleton O, Stockwell WR, Walcek CJ (1987) A three dimensional Eulerian acid deposition model: physical concepts and formulations. J Geophys Res 92:14681-14700

Davies S, Unam L (1999) Smoke-haze from the 1997 Indonesian forest fires: effects on pollution levels, local climate, atmospheric $\mathrm{CO}_{2}$ concentrations, and tree photosynthesis. For Ecol Manag 124:137-144

Dignon J, Eddleman H, Penner J (1994) A black carbon emission data base for atmospheric chemistry and climate studies. Technical report. Lawrence Livermore National Lab, Livermore, $\mathrm{CA}$

Duncan B, Bey I, Chin M, Mickley L, Fairlie T, Martin R, Matsueda H (2003) Indonesian wildfires of 1997: impact on tropospheric chemistry. J Geophys Res 108(D15):4458. doi:10.1029/2002JD003195

Energy Information Administration (2004) Indonesia: environmental issues. Technical report. Energy Information Administration. http://www.eia.doe.gov/emeu/cabs/indoe.html

Fang M, Huang W (1998) Tracking the Indonesian forest fire using NOAA/AVHRR images. Int J Remote Sens 19(3): 387-390

Frankenberg E, McKee D, Thomas D (2004) Health consequences of forest fires in Indonesia. California Center for Population Research On-Line Working Papers Series, CCPR-030-04

Fujiwara M, Kita K, Kawakami S, Ogawa T, Komala N, Saraspriya S, Suripto A (1999) Tropospheric ozone enhancements during the Indonesian forest fire events in 1994 and 1997 as revealed by ground-based observations. Geophys Res Lett 23(16):2417-2420

Fujiwara M, Kita K, Ogawa T, Kawakami S, Sano T, Komala N, Saraspriya S, Suripto A (2000) Seasonal variation of tropospheric ozone in Indonesia revealed by 5-year groundbased observations. J Geophys Res 105(D2):1879-1888

GEIA (2006) Available at: http://www.aero.jussieu.fr/projet/ ACCENT/database_table_inventories.php. Accessed November 2010

GPCC (2007) Available at: http://gpcc.dwd.de/. Accessed November 2010

Granier C, Niemeier U, Müller J-F, Olivier J, Peters J, Richter A, Nües H, Burrows J (2003) Variation of the atmospheric composition over the 1990-2000 period. Tech. Rep. 6, POET, EU project EVK2-1999-00011

Halmer MM, Schmincke DJ, Graf HF (2002) The annual volcanic gas input into the atmosphere, in particular into the stratosphere: a global data set for the past 100 years. J Volcanol Geotherm Res 115:511-528

Hauglustaine D, Brasseur G, Levine J (1999) A sensitivity simulation of tropospheric ozone changes due to the 1997 Indonesian fire emissions. Geophys Res Lett 26(21):33053308

Heil A (2007) Indonesian forest and peat fires: emissions, air quality, and human health. PhD thesis, Universität Hamburg. http://www.earthsystemschool.mpg.de/fileadmin/ user_upload/Documents/Theses/34_Thesis_Heil.pdf

Heil A, Goldammer J (2001) Smoke-haze pollution: a review of the 1997 episode in Southeast Asia. Reg Environ Change 2:24-37

Hilton D, Fischer TP, Marty B (2002) Noble gases and volatile recycling at subduction zones. In: Porcelli D, Ballentine CJ, Weiler R (eds) Reviews in Mineralogy and Geochemistrynoble gases in Geochemistry and Cosmochemistry, vol 47. Min Soc Am, Washington DC, pp 319-370 
Horowitz LW, Walters S, Mauzerall DL, Emmons LK, Rasch PJ, Granier C, Tie X, Lamarque JF, Schultz M, Tyndall G, Orlando J, Brasseur GP (2003) A global simulation of tropospheric ozone and related tracers: description and evaluation of Mozart, version 2. J Geophys Res 108(D24):4784. doi:10.1029/2002JD002853

Huffman G, Adler R, Arkin P, Chang A, Ferraro R, Gruber A, Janowiak J, McNab A, Rudolf B, Schneider U (1997) The Global Precipitation Climatology Project (GPCP) combined precipitation data set. Bull Am Meteorol Soc 78:5-20

Khandekar M, Murty T, Scott D, Baird W (2000) The 1997 El Niño, Indonesian forest fires and the Malaysian smoke problem: a deadly combination of natural and man-made hazard. Nat Hazards 21:131-144

Kita K, Fujiwara M, Kawakami S (2000) Total ozone increase associated with forest fires over the Indonesian region and its relation to the El Niño-southern oscillation. Atmos Environ 34:2681-2690

Kloster S (2006) DMS cycle in the ocean-atmosphere system and its response to anthropogenic perturbations. PhD thesis, Universität Hamburg. http://www.earthsystemschool.mpg. de/fileadmin/user_upload/Documents/Theses/Thesis_Kloster. pdf

Koe L, Arellano A Jr, McGregor J (2001) Investigating the haze transport from 1997 biomass burning in Southeast Asia: its impact upon Singapore. Atmos Environ 35:27232734

Ladstätter-Weißenmayer A, Meyer-Arnek J, Richter A, Wittrock F, Burrows J (2005) Tropospheric $\mathrm{O}_{3}$ over Indonesia during biomass burning events measured with GOME (Global Ozone Monitoring Experiment) and compared with trajectory analysis. Atmos Chem Phys Discuss 5:3105-3130

Langmann B (2000) Numerical modelling of regional scale transport and photochemistry directly together with meteorological processes. Atmos Environ 34:3585-3598

Langmann B, Heil A (2004) Release and dispersion of vegetation and peat fire emissions in the atmosphere over Indonesia 1997/1998. Atmos Chem Phys 4:2145-2160. www. atmos-chem-phys.org/acp/4/2145/

Matsueda H, Inoue H (1999) Aircraft measurements of trace gases between Japan and Singapore in October of 1993, 1996, and 1997. Geophys Res Lett 26(16):2413-2416

Matsueda H, Inoue H, Ishii M (1999) Large injection of carbon monoxide into the upper troposphere due to intense biomass burning in 1997. J Geophys Res 104(D21):2686726879

Mellor B, Yamada T (1974) A hierarchy of turbulence closure models for planetary boundary layers. J Atmos Sci 31:17911806

Nakajima T, Higurashi A, Takeuchi N, Herman J (1999) Satellite and ground-based study of optical properties of 1997 Indonesian forest fire aerosols. Geophys Res Lett 26(16): 2421-2424

Newhall CG, Self S (1982) The volcanic explosivity index (vei): an estimate of explosive magnitude for historical volcanism. J Geophys Res 87:1231-1238

Nho EY, Le Cloarec MF, Ardouin B, Tjetjep WS (1996) Source strength assessment of volcanic trace elements emitted from the Indonesian arc. J Volcanol Geotherm Res 74:121129

Olivier JGJ, Bouwman AF, van der Maas CWM, Berdowski JJM, Veldt C, Bloos JPJ, Visschedijk AJH, Zandveld PYJ, Haverlag JL (1996) Description of EDGAR version 2.0: a set of global emission inventories of greenhouse gases and ozone-depleting substances for all anthropogenic and most natural sources on a per country basis and on $1 \mathrm{x} 1$ grid. Tech rep, National Institute of Public Health and the Environment (RIVM), RIVM report nr. 771060 002. [TNO-MEP report nr. R96/119]

Penner J, Eddleman H, Novakov T (1993) Towards the development of a global inventory of black carbon emissions. Atmos Environ 27A:1277-1295

Pfeffer M, Langmann B, Graf HF (2006) Atmospheric transport and deposition of Indonesian volcanic emissions. Atmos Chem Phys 6:2525-2537

Podgorny I, Li F, Ramanthan V (2003) Large aerosol radiative forcing due to the 1997 Indonesian forest fire. Geophys Res Lett 30(1):1028. doi:10.1029/2002GL015979

Quah E (2002) Transboundary pollution in Southeast Asia: the Indonesian fires. World Dev 30(3):429-441

Randerson J, van der Werf G, Giglio L, Collatz G, Kasibhatla P (2006) Global Fire Emissions Database, version 2 (GFEDv2), Data set, Oak Ridge National Laboratory Distributed Active Archive Center, Oak Ridge, Tennessee, USA. http://daac.ornl.gov/

Richter A, Burrows J, Nüß H, Granier C, Niemeier U (2005) Increase in tropospheric nitrogen dioxide over China observed from space. Nature 437:129-132. doi:10.1038/nature04092

Sastry N (2002) Forest fires, air pollution, and mortality in Southeast Asia. Demography 39(1):1-23

Schnetzler CC, Bluth GJS, Krueger AJ, Walter LS (1997) A proposed volcanic sulfur dioxide index (vsi). J Geophys Res 102:20087-20092

Schultz M (2007) Reanalysis of the tropospheric chemical composition over the past 40 years (RETRO) - a long-term global modeling study of tropospheric chemistry final report. Tech rep, 5th EU framework programme

Schultz MG, Heil A, Hoelzemann JJ, Spessa A, Thonicke K, Goldammer JG, Held AC, Pereira JMC, van het Bolscher M (2008) Global emissions from wildland fires from 1960 to 2000. Glob Biogeochem Cycles 22, GB2002. doi:10.1029/2007GB003031

Simkin T, Siebert L (1994) Volcanoes of the world, 2nd edn. Geoscience Press in association with the Smithsonian Institution Global Volcanism Program, Tucson, CA

Smolarkiewitz PK (1983) A simple positive definite advection scheme with small implicit diffusion. Mon Weather Rev 111:476-479

Spiro PA, Jacob DJ, Logan DJ (1992) Global inventory of sulfur emissions with $1^{\circ} \times 1^{\circ}$ resolution. J Geophys Res 97:60236036

Stockwell WR, Middleton P, Chang JS, Tang X (1990) The second generation regional acid deposition model: chemical mechanism for regional air quality modeling. J Geophys Res 95:16343-16367

Syahril S, Resosudarmo B, Tomo H (2002) Study on air quality in Jakarta, Indonesia: future trends, health impacts, economic value and policy options. Technical report. Asian Development Bank

Thompson AM, Witte J, McPeters R, Oltmans S, Schmidlin F, Logan J, Fujiwara M, Kirchhoff V, Posny F, Coetzee G, Hoegger B, Kawakami S, Ogawa T, Johnson B, Vömel H, Labow G (2003) Southern hemisphere additional ozonesondes (shadoz) 1998-2000 tropical ozone climatology 1. Comparison with total ozone mapping spectrometer (toms) and ground-based measurements. J Geophys Res 108(D2):8238. doi:10.1029/2001JD000967

Tiedtke M (1989) A comprehensive mass flux scheme for cumulus parameterization in large-scale models. Mon Weather Rev 117:1778-1800 
Tsutsumi Y, Sawa Y, Makino Y, Jensen J, Gras J, Ryan B, Diharto S, Harjanto H (1999) Aircraft measurements of ozone, $\mathrm{NO}_{(x)}, \mathrm{CO}$, and aerosol concentrations in biomass burning smoke over Indonesia and Australia in October 1997: depleted ozone layer at low altitude over Indonesia. Geophys Res Lett 26(5):595-598

Wooster M, Ceccato P, Flasse S (1998) Indonesian fires observed using AVHRR. Int J Remote Sens 19(3):383-386
Yonemura S, Tsuruta H, Kawashima S, Sudo S, Peng L, Fook L, Johar Z, Hayashi M (2002a) Tropospheric ozone climatology over peninsular Malaysia from 1992 to 1999. J Geophys Res 107(D15):4229. doi:10.1029/2001JD000993

Yonemura S, Tsuruta H, Maeda T, Kawashima S, Sudo S, Hayashi M (2002b) Tropospheric ozone variability over Singapore from August 1996 to December 1999. Atmos Environ 36:2061-2070 